ISSN 2414-1143

Научный альманах стран Причерноморья. 2019. Том 17. № 1

DOI 10.23947/2414-1143-2019-17-1-48-55

UDC 94(47).073.5+94(47)

\title{
FEATURES OF THE FORMATION OF THE BRITISH-TURKISH DIPLOMACY OF THE SECOND HALF OF THE XIX CENTURY
}

\author{
(C) Elena K. Sklyarova, Olga N. Kamalova \\ Rostov State Medical University. Rostov-on-Don, Russian Federation \\ science-almanac@mail.ru
}

The article considers features of the formation of the British-Turkish diplomatic relations during the Victorian time. The diplomats and figures of the public health service who had the official and unofficial status during the Crimean War (1853-1856) and the Russian-Turkish War (1877-1878) defined the significant role in their development. Being engaged in parliamentary and diplomatic activity Austen Henry Layard was elected the lord-rector of the University of Aberdeen, he worked in the British Foreign Office, and he was appointed the first member of the commission of public works, which dealt with the issues of public health service. Considering his versatile abilities, periodic stay in Constantinople, knowledge of traditions of the Ottoman Empire he was appointed the ambassador of Great Britain in Constantinople. Before him, the British ambassador in Turkey the lord Stratford Canning took the influential position in Constantinople. This lord had a considerable impact on the formation of the Anglo-Turkish and Russian-Turkish relations. All the information obtained from $\mathrm{H}$. Layard was transferred by the lord Stratford Canning in his reports about the situation in the Ottoman Empire to the British Foreign Minister. In this period in Constantinople there was a race for power between the Reform party, Sultan and Rashchid Pasha's environment, various political groups. Turkey was in difficult economic and social situation, which was worsened by the influx of refugees and by the national and religious contradictions. The population movement defined the need of social reforms, new sanitary problems of army and the cities of empires. The British parliament carefully monitored the development of the Russian-Turkish relations on the eve of the Crimean War. The government of Britain was interested in disruption of the political relations between Russia and Turkey, and in the weakening of military-political power of the Russian Empire. The British press warmed up the negative attitude of Great Britain to Russia. Insanitary conditions of soldiers in the Crimea and Turkey became the subject of the parliamentary reports, having defined the formation of medical diplomacy. Successful maneuvering of the British government for the purpose of realization of their own military-political ambitions became the feature of the Anglo-Turkish relations of the Victorian time. London successfully used consequences of the Crimean War, knowledge and experience of the non-staff diplomats, their anti-Russians and pro-Turkish sentiments, the corresponding publications of the press for the weakening of the Russian Empire and the expansion of its own possession at the expense of Turkey.

Keywords: diplomacy, empire, Constantinople, the Ottoman Empire, Great Britain, the Russian Empire, Henry Layard, Florence Nightingale, the Crimean War.

\section{[Е.К. Склярова, О.Н. Камалова Особенности становления британо-турецкой дипломатии второй половины XIX века]}

Рассматриваются особенности становления британо-турецких дипломатических отношений в викторианскую эпоху. Значительную роль в их развитии определяли дипломаты и деятели общественного здравоохранения, имевшие официальный и неофициальный статус в период Крымской войны (1853-1856) и Русско-турецкой войны (1877-1878). Занимаясь парламентской и дипломатической деятельностью, Г. Лайярд был избран лорд-ректором университета Абердина, работал в Министерстве иностранных дел Британии, был назначен первым членом Комиссии общественных работ, которая занималась вопросами общественного здравоохранения. Учитывая его разносторонние способности, периодическое пребывание в Константинополе, знания традиций Османской империи он был назначен послом Великобритании в Константинополе. До него влиятельную позицию в Константинополе занимал британский посол в Турции лорд Стратфорд Каннинг, оказывая значительное влияние на фоомирование англо-турецких и российско-турецких отношений. Всю информацию, полученную от Г. Лайарда, лорд Стратфорд Каннинг передавал в своих донесениях о положении дел в Османской империи министру иностранных дел Британии. В этот период в Константинополе шла борьба за власть между партией реформ, окружением Султана и Ращид Паши, различными политическими группировками. Турция находилась в сложном социально-экономическом положении, ухудшающимся наплывом беженцев, национальными и религиозными противоречиями. Миграция населения определила необходимость социальных реформ, новые санитарные проблемы армии и городов империй. Британский парламент 
тщательно следил за развитием российско-турецких отношений накануне Крымской войны. Правительство Британии было заинтересовано в разрыве политических отношений между Россией и Турцией, ослаблением военно-политической мощи Российской империи. Негативное отношение Великобритании к России подогревалось британской прессой. Антисанитарные условия солдат в Крыму и Турции стали объектом парламентских отчётов, определив становление медицинской дипломатии. Особенностью англо-турецких отношений викторианской эпохи стало успешное маневрирование британского правительства с целью реализации собственных военно-политических амбиций. Лондон успешно использовал последствия Крымской войны, знания и опыт своих внештатных дипломатов, их антирусские и протурецкие настроения, соответствующие публикации прессы для ослабления Российской империи и расширения собственных владений за счёт Турции.

Ключевые слова: дипломатия, империя, Константинополь, Османская империя, Великобритания, Российская империя, Г. Лайярд, Ф. Найтингейл, Крымская война.

Elena K. Sklyarova - candidate of historical sciences, associate professor. Rostov State Medical University, Rostov-on-Don, Russian Federation.

Olga N. Kamalova - candidate of philosophical sciences, associate professor. Rostov State Medical University, Rostov-on-Don, Russian Federation.

Склярова Елена Константиновна - кандидат исторических наук, доцент. Ростовский государственный медицинский университет, г. Ростов-на-Дону, Российская Федерация.

Камалова Ольга Николаевна - кандидат философрских наук, доцент. Ростовский государственный медицинский университет, г. Ростов-на-Дону, Российская Федерация.

In the middle of the XIX century the British-Turkish diplomatic relations were defined, substantially, by the features of an economic and military-political role of these empires in the international community. The significant role in the development of diplomatic relations during the Victorian time was defined by the diplomats and figures of health service who had the official and unofficial status and also personal contacts with representatives of government circles of Britain and the Ottoman Empire. During this period the diplomatic relations of the empires were defined on the basis of their political goals in the years of the Crimean War (1853-1856) and the Russian-Turkish War (1877-1878). These problems got a certain coverage in the domestic historiography in the context of studying of the East problem and of the history of Turkey. However, the features of usage of the methods of official and unofficial Anglo-Turkish diplomacy during the time of the Queen Victoria's rule did not get a sufficient coverage.

Austen Henry Layard is known in the history as the archeologist, the collector, one of the discoverers of the Assyrian civilization, the head of excavations of the capitals of ancient Assyria (Kalakh and Nineveh), of Babylon and of the library of the King of Assyria Ashurbanipal [3]. Medical, philosophical, mathematical and astronomical treatises and also government decrees made up the main part of the library. In the XIX century during the Queen Victoria's time thanks to the archaeological activity of $\mathrm{H}$. Layard the expositions of the British museum were replenished with a number of unique historical finds of his expeditions (products made of ivory, sculptures, clay tablets (the VII century BC), palace gate, mosaics, basreliefs, the remains of the palace of governors of the Assyrian empire) [19]. In the XX century the copies of the well-known archeological finds of $\mathrm{H}$. Layard became an exposition basis about the history of Mesopotamia in the Pushkin museum in Moscow.

However, it is little-known that this uncommon native of France, the graduate of the university of Oxford, the politician and the diplomat was also the ambassador of Great Britain in Turkey. His family emigrated from France to England, and his ancestors had the Spanish roots on the mother's side. He spent a part of his youth together with his father in Italy. He got an education in England, France and Switzerland. He was always attracted by the countries of the East where he got acquainted with history, culture and medicine of Tur- 
key and also Syria, Serbia, Iraq and Iran. In the years of the Crimean War (1853-1856) H. Layard was in the Crimea. Later he lived in Constantinople at the British Embassy. Studying the East, he had learned the bases of patients' care, suffering from tropical diseases and also the bases of the East diplomacy.

In the middle of the XIX century, having left the successful archaeological activity, $\mathrm{H}$. Layard came back to England where he devoted himself to the foreign policy. In 1852-1857 and 1860-1869, he was elected the member of parliament of Great Britain (from Aylesbury). During the parliamentary debates with his participation, the issues of the military-political relationship of Great Britain, Turkey and Russia were periodically touched [15].

Being engaged in parliamentary and diplomatic activity, in $1855 \mathrm{H}$. Layard was elected the lord-rector of the oldest university of Aberdeen in Scotland. In 1861-1866 he worked in the British Foreign Office. During the work of an office of William Gladstone in $1868 \mathrm{H}$. Layard was appointed the first member of the commission of public works which dealt with the issues of public health service and public constructions [13, p.134]. During the Queen Victoria's time after the Crimean War there was an adoption of new laws "directed to the maintaining of health of the British nation and army, the formation of the appropriate public authorities of management, and the social policy of Great Britain" [5, p.101].

Considering the versatile abilities of the diplomat, periodic stay in Constantinople, knowledge of traditions of the Ottoman Empire and the difficult military-political situation, thanks to the lord Beaconsfield, in 1877-1880 Henry Layard was appointed the ambassador of Great Britain in Constantinople [20, p. 312].

The British ambassador in the Ottoman Empire the lord Stratford Canning played the significant role in the destiny of this politician. The diplomat took an influential position in Constantinople, having a considerable impact on the formation of the Anglo-Turkish and Russian-Turkish relationship. The lord Stratford Canning was also appointed the ambassador of Britain in Russia, but his mission was rejected by the decision of the Emperor Nicholas I [24, p. 2394].

The lord Stratford Canning and $\mathrm{H}$. Layard got acquainted in 1842 in Constantinople. Later in the autobiography $\mathrm{H}$. Layard noted that Stratford Canning as the experienced diplomat distinguished in him the outstanding abilities, having suggested him to stay in the Ottoman Empire in hope to find for him a suitable position in Constantinople in the British Embassy [18, p. 45]. For the long period the lord Canning had been the ambassador of Great Britain in the Ottoman Empire in 1825-1828, and then in 1842-1858. This experienced politician defined, substantially, the direction of the British-Turkish diplomatic relations in the XIX century.

Traveling in the 1840th around the provinces of the Ottoman Empire, $\mathrm{H}$. Layard informed the lord Stratford Canning on a local political situation, having described his observations in details in his autobiography. Being in Thessaloniki which was the province of the Ottoman Empire in that period, $\mathrm{H}$. Layard informed the lord on a local socio-political and economic situation, noting later that the deputy of Turkey in Thessaloniki Omar Pasha "was a Turk of an old school which was able neither to read, nor to write ..., and Thessaloniki was the prospering port promising to take the leading place in the trade affairs of the European provinces of the Ottoman Empire ... though there were no roads in that period". Traveling around Ambelakia, H. Layard noted that this city was a successful place of the Turkish dominion, but its management was taken by the incompetent administration that would ruin it soon. He faithfully spoke of other deputy of the Ottoman Empire, Namik Pasha, who had won the popularity among Muslims and Christians thanks to his liberal reforms. He was capable to implement the great reforms of Sultan Mahmoud. According to $\mathrm{H}$. Layard there were even friendship between them [18, pp. 23-28].

All the information obtained from $\mathrm{H}$. Layard was transferred by the lord Stratford Canning in his reports about the situation in the Ottoman Empire to the British Foreign Minister, 
the lord Aberdeen, who according to $\mathrm{H}$. Layard, was known for his favorable attitude towards Russia.

Being in Constantinople, $\mathrm{H}$. Layard described the socio-political situation of this city in details in 1842-1845. The member of parliament of Great Britain, the lord Stratford Canning, wishing to use $\mathrm{H}$. Layard's information in the military-political purposes, promised him at first only an unpaid position of the attaché in Constantinople, in Embassy of Great Britain, but also an opportunity to stay within the Ottoman Empire. However, this decision caused financial difficulties of $\mathrm{H}$. Layard, having forced him to take the burdensome credit in the bank.

In the 1840th in Constantinople, friendly relations between $\mathrm{H}$. Layard and Ahmed Vefik were established. Ahmed Vefik dreamt to become the Grand Vizier of the Ottoman Empire. He often invited H. Layard, they read Shakespeare and Dickens's works, discussed the ideas of political economy of Adam Smith and Ricardo, they also discussed political events of the Ottoman Empire, Great Britain and also the Russian Empire. Later the ambitious dreams of Ahmed Vefik came true and he became the Grand Vizier, and Henry Layard became the ambassador of Great Britain in Turkey.

The information which $\mathrm{H}$. Layard obtained in the house of Ahmed Vefika, meeting with his guests, he gave to the lord Stratford Canning and also published in the magazine "The Morning Chronicle" [18, p. 55]. In this period in Constantinople there was a race for power between the Reform party, Sultan and Rashchid Pasha's environment, various political groups. In this period, Turkey was in difficult economic and social situation, which was worsened by the influx of refugees and by the national and religious contradictions. In the suburb of Constantinople, Greeks, Armenians, Turks and natives of various countries of Europe lived. The population movement defined the need of social reforms, "new socioeconomic, legal, sanitary problems of the cities" of empires [21, p. 17]. The lord Stratford Canning and $\mathrm{H}$. Layard supported the Reform Party of Turkey, knowing their leaders personally.

The British parliament and the government carefully monitored the development of the Russian-Turkish and also Russian-Greek, French-Turkish relations on the eve of the Crimean War, they monitored the foreign policy of the emperor Alexander II, actions of Fuad Effendi, the Knyazh A.M. Gorchakov, the position of the governments of Austria and Serbia and also the diplomatic mission of the admiral A.S. Menshikov who in 1853 was sent as an Extraordinary Ambassador to Constantinople. The government of Britain was interested in disruption of the political relations between the Russian and Ottoman empires, in relocation of the British fleet from Malta to the coast of Turkey, in weakening of military-political power of Odessa. According to $\mathrm{H}$. Layard, Great Britain was ready for the war [16].

Being in Constantinople $\mathrm{H}$. Layard realized the danger of the foreign policy of Russia concerning Turkey. Having returned in May, 1853 to Great Britain, he began to undertake vigorous measures for protection of interests of the Ottoman Empire, believing that "helping Turkey is equitable to vital interests of Great Britain" [12, p. 140].

During the Victorian time the vigorous activity of $\mathrm{H}$. Layard "created for him a reputation of the most ardent supporter of Turks within all kingdom" [1, p. 61]. It helped him to keep the prestige and trust at the court of the Turkish sultan and his viziers, to achieve the stability of distribution of the pro-English sentiments there during the Crimean War (18531856) and the Russian-Turkish War (1877-1878).

The negative attitude of Great Britain to Russia was warmed up by the British press. In the middle of the Crimean War "The Economist magazine", welcoming the resignation of the founder of a system of public health service E. Chadwick, wrote cynically that "there is one nation in Europe where he would be invaluable where his researches, the aspiration to reach the end, the persistent and conscientious diligence, conviction in achievement of the goal, freedom of action would make the most salutary revolution; where almost everything demands changes, where people are slaves and voluntary slaves ... In the war in which we 
are involved we hope to destroy Kronshtadt, to take Sevastopol, to revolutionize Georgia" [23].

"The undeserved resignation of E. Chadwick took place against the background of the Crimean War, preparation of the Serfdom Reform and preservation of the autocracy in Russia" [22, p. 25]. During this period "E. Chadwick's activity seemed to the British incompatible with the century principles of local self-government and non-interference into the internal affairs of the country" [2, p. 19]. Only in 1889 "The Illustrated London News" described the ceremony devoted to the recognition of E. Chadwick's merits [17]. "From now he became a sir Edwin Chadwick!" The Lord Ebrington achieved the adoption of this belated decision at the national level. Queen Victoria signed the relevant decree. "The royal and state recognition came to Chadwick 35 years later, after his undeserved resignation" [8, p.137]. The name of the reformer only after a century took, by right, the place in textbooks on history of medicine of the XXI century [7, p. 105].

The similar fate comprehended the Member of Parliament and the diplomat H. Layard. During the work of the Prime Minister W. Gladstone, $\mathrm{H}$. Layard was displaced from his post, and he was not awarded the peerage. The similar fate comprehended many outstanding reformers both in Great Britain and in Russia, these reformers didn t belong to the aristocracy by their origin. However, the merits of the reformer $\mathrm{E}$. Chadwick, as well as the British Diplomat $\mathrm{H}$. Layard were reached thanks to their outstanding abilities exclusively. The politicians were familiar, defining the dynamic development of the British Empire.

After the returning from the Crimea $\mathrm{H}$. Layard wrote the book "The First Crimean Company" in which as historians specified, the hostile attitude of the author towards Russia was noted [10, p.186]. Nevertheless, having seen insanitary conditions of soldiers in the Crimea and Turkey and incompetence of the British military command, $\mathrm{H}$. Layard reported on this in the parliament. After the corresponding investigation the army chiefs left the posts, but the politician had personal enemies who modified his surname as "strongly lying" [18, $p$. 271].

"The Crimean War is the first war where there were female physicians and also journalists. Their stories about the heartless attitude towards wounded people caused scandal in Britain. The wounded were doomed to the death in insanitary hospitals which teemed with rats" [9, p.163]. Dependence of increase in mortality of the population on social conditions "became the subject of special parliamentary reports, of socio-medical and statistical researches and also of a package of the new social laws which caused ... the formation of health care system and social policy of Great Britain" [6, p. 69].

The Crimean War became the first war in the history reflected in photos, in the government and diplomatic reports [14, p. 64]. Florence Nightingale's museum, created in London, is a reflection of history of the Crimean War, of formation of the Victorian medical diplomatic activity [4, p. 45]. "The medal of Florence Nightingale is an award of the International Committee of the Red Cross which is awarded to the nurses for exclusive devotion and bravery at assistance to the wounded and the sick" [11, p.108].

In 1878, being a pro-Turkish politician and a diplomat, being in the friendly relations with representatives of the yard of the Turkish sultan, $\mathrm{H}$. Layard promoted signing of the allied treaty between Great Britain and Turkey on the basis of which, the island of Cyprus which was a part of the Ottoman Empire passed to Great Britain. In the new international treaty, Russia agreed with the Great Britain conditions concerning the degree of autonomy and division of Bulgaria borders. While signing the Anglo-Turkish and Cyprian convention of 1878, London skillfully used the desire of Russia to get Batumi, emphasizing the intentions of Britain on protection of the Turkish lands. However, the international conferences in Paris (1856), in Constantinople (1876) and in London (1877) proved that the fate of the Ottoman Empire and its territories was solved for the benefit of the Victorian diplomacy. Temporary 
neutralization of the Black Sea, weakening of the Russian Empire, the reduction of territories of the Ottoman Empire became the results.

Thus, the successful maneuvering of the British government for the purpose of realization of its own military-political relations became the feature of the Anglo-Turkish diplomatic relations of the Victorian time. The Crimean War defined the formation of the Victorian medical diplomatic activity. London successfully used consequences of the Crimean War, knowledge and experience of the non-staff diplomats, their anti-Russians and pro-Turkish sentiments, the corresponding publications of the press for the weakening of the Russian Empire and the expansion of its own possession at the expense of Turkey.

\section{Лumepamypa}

1. Герцог Аргалийский. Ответственность Англии в восточном вопросе. СПб., 1908. C. 61.

2. Гутиева М.А., Склярова Е.К. Сравнительный анализ социальных реформ России и Великобритании в первой половине XIX века // Гуманитарные и социальные науки. 2015. № 1. С. 19.

3. Лейард Остин Генри. Большая советская энциклопедия. В 30 т. / под ред. А.М. Прохорова. 3-е изд. М.: Советская энциклопедия, 1969.

4. Камалова О.Н., Склярова Е.К. Историко-медицинские экспонаты и музеи Великобритании // Медицинский музей и медицинская коммуникация. Сборник материалов IV Всероссийской научно-практической конференции "Медицинские музеи России: состояние и перспективы развития". Московский государственный медико-стоматологический университет имени А.И. Евдокимова. 2017. С. 45.

5. Макарова В.Н., Склярова Е.К., Жбанникова М.И. Викторианская урбанизация и здоровье нации // Комплексная безопасность государства и общества материалы международной научно-практической конференции. Филиал «Московский университет им. С.Ю. Витте» в г. Ростове-на-Дону. 2017. С. 101.

6. Макарова В.Н., Склярова Е.К., Чубарян В.Т. Викторианская урбанизация и проблема смертности и здравоохранения в Великобритании // Гуманитарные и социально-экономические науки. 2014. № 2 (75). С. 69.

7. Склярова Е.К., Камалова О.Н. Философские аспекты викторианского здравоохранения // Экономические и гуманитарные исследования регионов. 2015. №. 1. C. 103-108.

8. Склярова Е.К., Котова T.А. Эдвин Чедвик - создатель системы общественного здравоохранения. Подарок России или Великобритании. Ростов н/Д, 2011. С. 137.

9. Склярова Е.К., Переверзева Д.О., Камалова О.Н. Флоренс Найтингейл и лорд Герберт в годы Крымской войны // Медики - герои войн и локальных конфлликтов. Материалы Всероссийской научно-практической конференции с международным участием. Ростов-на-Дону, 2017. С. 163.

10. Тарле Е.В. Крымская война М., 1950. Т. 2. С. 186.

11. Харламов Е.В., Склярова Е.К., Киселёва О.Ф. Милосердие как призвание. Ростов-на-Дону, 2017. С. 108.

12. Человек второго плана в истории. Ростов-на-Дону, 2006. Вып. 3. С. 140.

13. Eminent Persons. Vol. VI. L., 1897. P. 134.

14. English medium: History. Sklyarova E.K., Gutieva M.A., Gafiyatullina G.Sh., Kamalova O.N. Ростов-на-Дону, 2018. C. 64.

15. Hansard's Parliamentary Debates. 3-rd Series. 1853. Vol. 128. c.1427 - 1429; Vol. 129. c. $648-652$.

16. Hansard's Parliamentary Debates. 3-rd Series. 1853. Vol. 129. c. 1760 - 1811. 
17. Illustrated London News. 1889. March 23.

18. Layard H. A. Autobiography and letters from his childhood until his appointment as H.M. Ambassador at Madrid. Ed. by W. Bruce. L., 1903. Vol. II. P. 23 - 28, 45, 55, 271.

19. Layard $H$. Discoveries in the ruins of Nineveh and Babylon with travels in Armenia, Kurdistan and the Desert being the result of a second expedition undertaken for the Trustees of the British museum. L., 1853.

20. Layard, Sir Austen Henry // Encyclopedia Britannica. 11-th ed. Vol. 16. Cambridge: Cambridge University Press. P. 312.

21. Sklyarova E.K. Comparative aspects of scientific research of the urbanization problem // Научный альманах стран Причерноморья. 2016. № 2 (6). С. 17.

22. Sklyarova E.K Crimean war and establishing of public health system in Great Britain // Научный альманах стран Причерноморья. 2017. № 1 (9). С. 25.

23. The Economist. 1854. Aug. 5.

24. The London Gazette. 1832. 30 October. P. 2394.

\section{References}

1. Gertsog Argaliiskii. Otvetstvennost' Anglii v vostochnom voprose. [Duke of Argyll. Responsibility of England in the East question] Saint Petersburg, 1908. 61 p. (in Russian).

2. Gutieva M.A., Sklyarova E.K. Sravnitel'nyi analiz sotsial'nykh reform Rossii i Velikobritanii v pervoi polovine XIX veka. Gumanitarnye i sotsial'nye nauki. [The comparative analysis of social reforms of Russia and Great Britain in the first half of the XIX century. Humanitarian and social sciences]. 2015. No. 1. 19 p. (in Russian).

3. Austen Henry Layard Bol'shaia sovetskaia entsiklopediia. [Great Soviet Encyclopedia] In 30 volumes. Under the editorship of A.M. Prokhorov. The third edition. Moscow: Soviet encyclopedia, 1969 (in Russian).

4. Kamalova O.N., Sklyarova E.K. Istoriko-meditsinskie eksponaty i muzei Velikobritanii. Meditsinskii muzei i meditsinskaia kommunikatsiia Sbornik materialov IV Vserossiiskoi nauchno-prakticheskoi konferentsii "Meditsinskie muzei Rossii: sostoianie i perspektivy razvitiia". [Historical and medical exhibits and museums of Great Britain. Medical museum and medical communication. Collection of materials of the fourth All-Russian scientific and practical conference "Medical museums of Russia: condition and prospects of development"]. A.I. Yevdokimov Moscow State University of Medicine and Dentistry. 2017. 45 p. (in Russian).

5. Makarova V.N., Sklyarova E.K., Zhbannikova M.I. Viktorianskaia urbanizatsiia i zdorov'e natsii. Kompleksnaia bezopasnost' gosudarstva i obshchestva materialy mezhdunarodnoi nauchno-prakticheskoi konferentsii. [Victorian urbanization and health of the nation. Complex safety of the state and society. Materials of the international scientific and practical conference]. The branch of the private educational institution of higher education "S.Yu. Witte Moscow University" in Rostov-on-Don, 2017. 101 p. (in Russian).

6. Makarova V.N., Sklyarova E.K., Chubarian V.T. Viktorianskaia urbanizatsiia i problema smertnosti i zdravookhraneniia v Velikobritanii. Gumanitarnye i sotsial'noekonomicheskie nauki. [Victorian urbanization and the problem of mortality and health service in Great Britain. Humanitarian and social and economic sciences]. 2014. No. 2 (75). 69 p. (in Russian).

7. Sklyarova E.K., Kamalova O.N. Filosofskie aspekty viktorianskogo zdravookhraneniia. Ekonomicheskie i gumanitarnye issledovaniia regionov. [Philosophical aspects of the 
Victorian health service. Economic and humanitarian researches of regions]. 2015. No. 1. pp. 103-108 (in Russian).

8. Sklyarova E.K., Kotova T.A. Edvin Chedvik - sozdatel' sistemy obshchestvennogo zdravookhraneniia. Podarok Rossii ili Velikobritanii. [Edwin Chadwick is a creator of the system of public health service. Gift of Russia or Great Britain]. Rostov-on-Don, 2011. 137 p. (in Russian).

9. Sklyarova E.K., Pereverzeva D.O., Kamalova O.N. Florens Naitingeil i lord Gerbert v gody Krymskoi voiny. Mediki - geroi voin i lokal'nykh konfliktov. [Florence Nightingale and the lord Herbert in the years of the Crimean War. Physicians are heroes of wars and local conflicts. Materials of the All-Russian scientific and practical conference with the international participation]. Rostov-on-Don, 2017. 163 p. (in Russian).

10. Tarle E.V. Krymskaia voina. [The Crimean War] Moscow, 1950. Vol. 2. 186 p. (in Russian).

11. Kharlamov E.V., Sklyarova E.K., Kiseleva O.F. Miloserdie kak prizvanie. [Mercy as a calling] 2017. 108 p. (in Russian).

12. Chelovek vtorogo plana $v$ istorii. [The person of the second plan in the history]. Issue 3. 2006. 140 p. (in Russian).

13. Eminent Persons. Vol. VI. L., 1897. 134 p.

14. English medium: History. Sklyarova E.K., Gutieva M.A., Gafiyatullina G.Sh., Kamalova O.N. Rostov-on-Don, 2018. 64 p. (in Russian).

15. Hansard's Parliamentary Debates. 3-rd Series. 1853. Vol. 128. pp. 1427 - 1429; Vol. 129. pp. $648-652$.

16. Hansard's Parliamentary Debates. 3-rd Series. 1853. Vol. 129. pp. $1760-1811$.

17. Illustrated London News. 1889. March 23.

18. Layard H. A. Autobiography and letters from his childhood until his appointment as H.M. Ambassador at Madrid. Ed. by W. Bruce. L., 1903. Vol. II. p. 23 - 28, 45, 55, 271.

19. Layard $H$. Discoveries in the ruins of Nineveh and Babylon with travels in Armenia, Kurdistan and the Desert being the result of a second expedition undertaken for the Trustees of the British museum. L., 1853.

20. Layard, Sir Austen Henry. Encyclopedia Britannica. 11-th ed. Vol. 16. Cambridge: Cambridge University Press, $312 \mathrm{p}$.

21. Sklyarova E.K. Comparative aspects of scientific research of the urbanization problem. Science almanac of Black Sea region countries. 2016. No. 2 (6). 17 p.

22. Sklyarova E.K Crimean war and establishing of public health system in Great Britain. Science almanac of Black Sea region countries. 2017. No. 1 (9). 25 p.

23. The Economist. 1854. Aug. 5.

24. The London Gazette. 1832. 30 October. 2394 p. 